УДК 334.021:005.56

DOI: $10.15673 /$ fie.v13i2.2034

\author{
Купріна H.M. \\ доктор економічних наук, доцент \\ кафедра обліку та аудиту \\ Одеська національна академія харчових технологій \\ вул. Канатна 112, м. Одеса, Україна, 65039E-mail: k.natali_@ukr.net \\ ORCID ID: 0000-0003-4645-545X
}

\title{
РОЗВИТОК СУЧАСНИХ БІЗНЕС-СТРАТЕГІЙ ТА АУТСОРСИНГОВОЇ ДІЯЛЬНОСТІ СУБ'ЄКТІВ НАЦІОНАЛЬНОЇ ЕКОНОМІКИ: СУТНІСТЬ ТА НАПРЯМИ
}

\begin{abstract}
В сучасних умовах діяльності та розвитку суб'єктів національної економіки України актуальним $€$ дослідження зарубіжного досвіду та досліджень вітчизняними ученими сучасних бізнес-стратегій та впровадження нових напрямів діяльності суб'єктів національної економіки для забезпечення ефективності їх функціонування та конкурентоспроможності. Дослідження публікацій учених показало, що аутсорсинг, як напрям діяльності на підставі ділового партнерства, трактується не однаково, але сучасні глобальні тенденції у розвитку діяльності підприємств спрямовані у сферу послуг та інформаційних технологій та отримання «ключових компетенцій», заснованих на співпраці і соконкуренціі, використанні переваг малих і середніх підприємств. Обґрунтовано, що для забезпечення конкурентоспроможності та ефективності функціонування суб'єктів національної економіки в Україні необхідна їх економічна транссоормація - персистентна, де м'якою трансформацією діяльності є саме здійснення аутсорсингової діяльності суб'єктів на основі різних підходів та видів аутсорсингу. Розроблена система критеріальної оцінки персистентної трансформації харчової промисловості в системі оцінювання персистентності діяльності їі суб'єктів в контексті забезпечення ії конкурентоспроможності.

Ключові слова: аутсорсинг, аутсорсингова діяльність, суб'єкти національної економіки, персистентність діяльності, персистентна трансформація діяльності, забезпечення конкурентоспроможності.
\end{abstract}

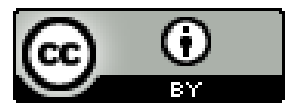

This work is licensed under a Creative Commons Attribution 4.0 International License http://creativecommons.org/licenses/by/4.0/
Постановка проблеми та їі зв'язок з важливими науковими та практичними завданнями. Сучасний стан та розвиток національної економіки не можливий без сильних господарюючих суб'єктів, які $\epsilon$ конкурентоспроможними, як на внутрішньому ринку, так й мають можливість просування та функціонування на зовнішніх ринках. Тому, як показало попереднє наше дослідження, в умовах зміни факторів зовнішнього середовища належну конкурентоспроможність набуває країна, яка має ефективно функціонуючі і конкурентоспроможні суб'єкти підприємницької діяльності, які формують діяльність відповідно до стратегії власного розвитку та можуть стабільно розвиваються під впливом всього спектру глобалізаційних процесів, де економічні $є$ саме домінуючими.

У сучасні умови розвитку економіки країн вимагають у даний час пошуку таких методів захисту вітчизняних товаровиробників, які саме сприяють збереженню ефективності діяльності та конкурентоспроможності суб'єктів національної економіки, та пошуку напрямів їх розвитку та стабільного функціонування.

Одним 3 таких напрямів сучасних бізнесстратегій є саме ділове партнерства та такої системи кооперації підприємств, як аутсорсинг, що потребує вивчення досвіду зарубіжних країн та досліджень вітчизняних науковців.

Аналіз останніх досліджень і публікацій. Наше дослідження показало [1, с. 73-96], що українські вчені розглядають зарубіжний різний досвід ділового партнерства та застосування моделей аутсорсингу та аутсорсингової діяльності за напрямами:

- застосування інновацій та розширення використання венчурних стратегій і інформаційних технологій для підвищення конкурентоспроможності національної економіки [2];

- впровадження інвестиційних проектів щодо енергозбереження діяльності підприємств та суб'єктів діяльності житлово-комунального господарства [3];

- створення вертикально інтегрованих структур на основі спеціалізації на умовах логістичного підходу, наприклад, зернових кластерів [4];

- розвитку суб'єктів малого бізнесу в харчовій промисловості [238] тощо.

Проблема забезпечення ефективності діяльності та конкурентоспроможності суб'єктів національної економіки України $є$ актуальною в сучасних умовах та потребує дослідження аусторсингу, як напряму ділового партнерства та виду діяльності, та 
особливостей розвитку аутсорсингової діяльності в Україні.

Формулювання цілей дослідження. Метою даної статті $є$ дослідження сутності аутсорсингу, як сучасного напряму діяльності суб'єктів національної економіки, та аспектів його застосування в системі їх економічної трансформації для забезпечення ефективності функціонування, конкурентоспроможності та підтримки вітчизняного виробника в Україні.

Виклад основних результатів та їх обгрунтування. Наше дослідження показало [1, с.72-74], що світова тенденція системної інтеграції підприємств та їх підрозділів в останні роки набуває все більших масштабів, змушуючи створювати інтегровані комплекси різного роду і масштабу, що сприяє підвищенню ефективності всіх видів діяльності підприємства та посилення конкурентоспроможності. Здійснення такої інтеграції позитивно впливає на величину витрат підприємства. Так, на ранніх етапах розробки виробу можна добитися значної економії в його вартості: залучення підприємств і організацій, що займаються постачанням та постачальників на початковому етапі проектування та розроблення може привести до скорочення витрат до $18 \%$, залучення сторонніх ресурсів призводить до скорочення складських запасів більш ніж на $30 \%$, а своєчасність поставок збільшується до $73 \%[6]$

Дослідження публікацій вчених показало, що аутсорсинг, як напрям діяльності на підставі ділового партнерства, трактується не однаково (табл. 1), але найбільш поширеними в аутсорсингової діяльності $є$ даний час $є$ IT-аутсорсинг, ITC-аутсорсинг, аутсорсинг бізнес процесів (повний і частковий), виробничий аутсорсинг (у тому числі контрактинг та субконтрактинг) [1, с. 78-80].

Таблиця 1

Дослідження підходів щодо визначення сутності аутсорсінгу, як напряму діяльності субєктів національної економіки (фрагмент)*

\begin{tabular}{|c|c|}
\hline Автор, джерело & Сутність категорії «аутсорсинг» \\
\hline \multirow{2}{*}{$\begin{array}{l}\text { Н. Шлафман [3, с. } 224, \\
\text { 227] }\end{array}$} & $\begin{array}{l}\text { Передача на договірній основі деяких (зазвичай непрофільних) функцій (процесів, } \\
\text { напрямків діяльності) стороннім організаціям, які володіють відповідними техніч- } \\
\text { ними засобами та (або) управлінськими знаннями в будь-якій конкретній області } \\
\text { (сфері компетенцій). }\end{array}$ \\
\hline & $\begin{array}{l}\text { Схему надання послуг, при якій зовнішньому підряднику віддається допоміжний } \\
\text { процес, який є на підприємстві (або в організації) постійно, щодня, а не виникає } \\
\text { час від часу; необхідно істотне підстроювання послуг підрядної організації до ви- } \\
\text { мог конкретного підприємства (або організації), тому що даний процес досить си- } \\
\text { льно пов'язаний з іншими організаційними процесами. }\end{array}$ \\
\hline I. Савенко [7, с. 5] & $\begin{array}{l}\text { Масштабний (великий) проект, коли аутсорсеру повністю передається частина } \\
\text { бізнесу; передача певних функцій організації третій особі, яка спеціалізується в цій } \\
\text { галузі. }\end{array}$ \\
\hline $\begin{array}{l}\text { Г. Хамел, } \\
\text { К. Прахалад, [8, с. } 83]\end{array}$ & $\begin{array}{l}\text { Передачу традиційних непрофільних, допоміжних функцій, таких як бухгалтерсь- } \\
\text { кий облік, розробка та створення інформаційних систем, господарське обслугову- } \\
\text { вання, зберігання, транспортування та іншим зовнішнім виконавцям - аутсорсе- } \\
\text { рам, субпідрядникам, висококваліфікованим фахівцям сторонніх підприємств } \\
\text { організацій, для яких дана функція є основною діяльністю, } 3 \text { метою скорочення } \\
\text { операційних витрат. }\end{array}$ \\
\hline $\begin{array}{l}\text { В. Кислый, } \\
\text { Т. Жарик, [9, с. 30-37] }\end{array}$ & $\begin{array}{l}\text { Спеціалізація підприємств на основі логістичного підходу (виконання логістичних } \\
\text { послуг) як процесу поглиблення розподілу праці. }\end{array}$ \\
\hline $\begin{array}{l}\text { А. Товстих, [10, с. } 41- \\
\text { 42] }\end{array}$ & $\begin{array}{l}\text { Три основних функції охоплюють діяльність підприємства - це розробка товарів } \\
\text { (продукції), реалізація та обслуговування клієнтів, а на аутсорсинг направляються: } \\
\text { виробництво таких товарів, маркетинг і логістика, фінансові та інші операції, щоб } \\
\text { потім споживатися в якості послуг }\end{array}$ \\
\hline
\end{tabular}

* Складено на підставі джерел [3,7-10]

Як показали наші дослідження публікацій вчених, які присвячені вивченні напрямів аутсорсингової діяльності [1, с. 74-80], аутсорсинг не обмежується тільки логістичним підходом, а сучасні глобальні тенденції у розвитку діяльності підприємств спрямовані у сферу послуг та інформаційних технологій, яка полягає в отриманні «ключових компетенцій» (стратегії «win-win»), заснованих на співпраці i соконкуренціi, використанні переваг малих і середніх підприємств, що підтверджується й зарубіжним досвідом державно-приватного партнерства щодо спри- яння розробки та впровадження нових технологій на основі різних коопераційних угод приватних промислових компаній, університетів, науково-дослідних лабораторій, інших організацій та урядових відомств. Так, наприклад у США, з метою підвищення рівня $\mathrm{i}$ просування наукових досліджень та 3 фінансуванням державою пріоритетних напрямів таких досліджень, надається можливість національним компаніям протистояти жорсткій ринковій конкуренції та $є$ способом підтримки державою національного приватного бізнесу. 
Наші дослідження підтверджують [1, с. 178191], що для забезпечення конкурентоспроможності та ефективності функціонування суб'єктів національної економіки в Україні необхідна їх економічна трансформація, яка у сформованих умовах господарювання ii суб'єктів, спрямована на жорстку, помірну та м'яку їх трансформацію: формування інтегрованих формувань вертикального типу, які в сучасних умовах мають більш високу стійкість до «виживання» на внутрішньому ринку і забезпечення конкурентоспроможності та можливості ефективності їх діяльності і подальшого розвитку, перспективи виходу і здатності до активної конкуренції на міжнародних ринках (холдинги - жорстка трансформація діяльності, кластерні формування та асоціації - помірна трансформація діяльності, здійснення діяльності підприємств на основі інших підходів та видів аутсорсингу - м'яка трансформація діяльності).

Як показало наше попереднє дослідження [1, c. 191-192], адаптація - більш м'який процес пристосування до зовнішнього середовища, ніж трансформація або реорганізація i, в даному контексті, необхідно враховувати не принцип адаптивності, а прин- цип імпаритету, як способу відповідної реакції на агресивну зміну зовнішнього середовища. Так, в контексті проведеного дослідження, було обгрунтовано, що адаптація $є$ більш широким поняттям, чим імпаритет або імпаритетність, тому що враховує не тільки агресивний вплив зовнішнього конкурентного середовища, але й такі внутрішні зміни, як зміна податкового законодавства, зміна національних стандартів та законодавчих актів на міжнародні та їх адаптація, зміну законодавчих актів в частині грошового обігу тощо, що суттєво впливає на діяльність харчової промисловості та її суб'єктів.

Тому, об'єктивним є виділення нової категоpiї - «персистентність» та виду трансформації діяльності харчової промисловості та ії суб'єктів - «персистентної трансформації», та їі обгрунтування. Категорія «персистентність діяльності» відображає ступінь економічної стійкості об'єкту дослідження до впливу факторів зовнішнього середовища та відображає достатній рівень ефективності його функціонування і конкурентоспроможності (рис. 1) [1, с. 191$193]$.

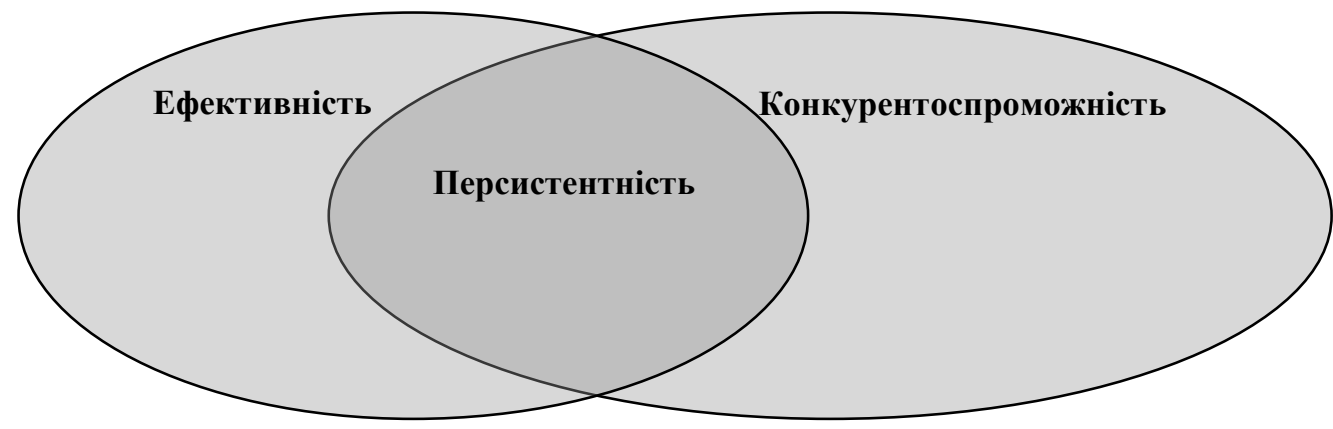

Рис. 1 - Взаємозв'язок категорій «ефективність» $\mathbf{i}$ «конкурентоспроможність» суб'скта національної економіки*

* авторська розробка [1, с. 192]

На нашу думку, «персистентна трансформація суб'єктів харчової промисловості», яка розуміється як м'яка, помірна або жорстка трансформація власної діяльності суб'єктів харчової промисловості, проведена на основі аналізу персистентності їх діяльності та критеріальної оцінки і спрямована на формування інтегрованих формувань та об'єднань суб'єктів, які в сучасних умовах мають більш високу стійкість до «виживання» на внутрішньому ринку і можливість забезпечення конкурентоспроможності та підвищення ефективності власної діяльності і подальшого розвитку, а, отже, здатності до активної конкуренції на міжнародних ринках [1, с. 191-200].

Так, такий підхід до вибору ступеню трансформації та оцінки функціонування суб'єктів галузі, вибір саме категорії «персистентність діяльності» та відмова від поняття «стійкість», «стабільність» багато в чому пов'язаний 3 широким застосуванням даних термінів в різних сферах економічної науки на рівні дослідження функціонування підприємства: фінансова стійкість, стратегічна стійкість, технологічна стійкість, стабільність діяльності, стабільність розвитку тощо. Даний підхід дозволяє виділити взаємозв'язок категорій «ефективність діяльності» суб'єкта національної економіки, наприклад, харчової промисловості, та його «конкурентоспроможність», що як раз розглядається при проведенні оцінки конкурентоспроможності об'єкту дослідження з використанням методів, що базуються на теорії ефективної конкуренції [11].

Як показало наше попереднє дослідження [11], необхідно враховувати прагнення і здатність економічної системи, наприклад, харчової промисловості та її суб'єктів, не тільки зберігати рівноважний стан, що характеризує стійкість, стабільність, але, в той же час, мати здатність до розвитку й змін, а при агресивному впливу факторів зовнішнього середовища - до стійкого «вичікування» у здійсненні своєї діяльності, але не до їі припинення. Тому для вибору 
оцінки діяльності суб'єктів національної економіки в сучасних умовах не підходять такі терміни як «перманентність» ((фран. «permanent», від латинського «permaneo» - залишаюся, продовжуюсь), безперервно триває, постійний), «фіксованість» (від англ. «fixity» - нерухомість, стійкість), «гомеостазіс» (прагнення і здатність економічної системи зберігати рівноважний стан, що характеризує стійкість, стабільність і, в той же час збереження консервативності системи). Персистентность (від лат. «persisto» - залишаюся, завзятість) - це властивість будь-чого підтримувати постійній (сталий) стан, не виключая сталий розвиток i функціонування та підлягає широкій варіативності, а не припинення діяльності під впливом факторів зовнішнього середовища [1, с. 193].

Дослідження підтвердило [11], що даний термін не використовувався в економічній науці, а в основному застосовується в області екології, біології, математики, а в останні роки і в інформаційних технологіях. В табл. 2 сформована система критеріальної оцінки персистентної трансформації харчової промисловості, в контексті забезпечення ii конкурентоспроможності, з видаленням [1, с. 197-199]:

- виду такої трансформації: м'яка, помірна, жорстка

- оцінювання загальних показників конкурентоспроможності харчової промисловості та ii суб'єктів за обраними методами та рівнями дослідження - мезо-, мікро-, міні- та нано-;

- оцінювання часткових показників оцінки ефективності функціонування суб'єктів харчової промисловості за мезо-, мікро-, міні- та нанорівнями дослідження, з урахуванням наявності або відсутності нормативних значень.

Таблиця 2

\section{Персистентна трансформація харчової промисловості та її оцінювання} в системі забезпечення конкурентоспроможності *

\begin{tabular}{|c|c|c|c|}
\hline \multirow{2}{*}{$\begin{array}{l}\text { Вид трансфо- } \\
\text { рмації суб'єкту } \\
\text { харчової } \\
\text { промисловості }\end{array}$} & \multirow{2}{*}{$\begin{array}{c}\text { Відносне відхилен- } \\
\text { ня значення } \\
\text { загальних показни- } \\
\text { ків конкурентосп- } \\
\text { роможності }\end{array}$} & \multicolumn{2}{|c|}{$\begin{array}{c}\text { Відхилення значення часткових показників оцінки ефективності } \\
\text { функціонування суб’єкту харчової промисловості за КЕФ- та ЕФК- } \\
\text { аналізом }\end{array}$} \\
\hline & & $\begin{array}{c}\text { Мають } \\
\text { нормативне значення }\end{array}$ & $\begin{array}{c}\text { Не мають } \\
\text { нормативного значення }\end{array}$ \\
\hline 1. М'яка & $\begin{array}{l}\text { Відсутність зрос- } \\
\text { тання, не стійка те- } \\
\text { нденція та коливан- } \\
\text { ня }\end{array}$ & $\begin{array}{l}\text { Негативні відхилення від } \\
\text { нормативних значень, відсутність } \\
\text { тенденції до покращення }\end{array}$ & $\begin{array}{l}\text { Відсутність зростання, } \\
\text { не стійка тенденція та } \\
\text { коливання }\end{array}$ \\
\hline 2. Помірна & Зменшення до 20\% & Зменшення до 20\% & $\begin{array}{l}\text { Тенденція до коливання, } \\
\text { зменшення до } 20 \%\end{array}$ \\
\hline 3.Жорстка & Зменшення до 50\% & Зменшення до 50\% & $\begin{array}{l}\text { Стійка тенденція до зменшен- } \\
\text { ня або до негативного їх зна- } \\
\text { чення }\end{array}$ \\
\hline
\end{tabular}

* Авторська розробка [1, с. 199]

М'яка трансформація діяльності суб'єктів національної економіки, а саме аутсорсингова діяльність $є$ ефективним напрямом покращення діяльності на підставі ділового партнерства при відсутності зростання та нестійкої тенденції до коливання загальних показників конкурентоспроможності на підставі методів оцінювання, що базуються на теорії ефективної конкуренції, що запропоновано та розроблено нами [1, с. 194-209, 295-299] й підтверджено проведеними дослідженнями, та буде сприяти, на нашу думку, забезпеченню ефективності іiі функціонування та конкурентоспроможності.

Висновки та перспективи подальших досліджень. Проведене дослідження дозволило отримати певні результати і зробити наступні висновки:

- світова тенденція системної інтеграції підприємств та їх підрозділів в останні роки набуває все більших масштабів, змушуючи створювати інтегровані комплекси різного роду і масштабу, що сприяє підвищенню ефективності всіх видів діяльності підприємства та посилення конкурентоспроможності, а здійснення такої інтегрованої діяльності позитивно впливає на функціонування суб'єкту господарювання та його розвиток;

- дослідження публікацій вчених показало, що аутсорсинг, як напрям діяльності на підставі ділового партнерства трактується не однаково, але найбільш поширеними в аутсорсингової діяльності є даний час є IT-аутсорсинг, ITC-аутсорсинг, аутсорсинг бізнес процесів (повний і частковий), виробничий аутсорсинг (у тому числі контрактинг та субконтрактинг). Але аутсорсинг не обмежується тільки логістичним підходом, а сучасні глобальні тенденції у розвитку діяльності підприємств спрямовані у сферу послуг та інформаційних технологій та отримання «ключових компетенцій», заснованих на співпраці і соконкуренціi, використанні переваг малих і середніх підприємств, що підтверджується й зарубіжним досвідом державно-приватного партнерства;

- обгрунтовано, що для забезпечення конкурентоспроможності та ефективності функціонування суб'єктів національної економіки в Україні необхідна їх економічна трансформація - персистентна, яка у сформованих умовах господарювання іiі суб'єктів, 
спрямована на жорстку, помірну та м'яку їх трансформацію, де м'яка трансформація діяльності - це саме здійснення аутсорсингової діяльності суб'єктів на основі різних підходів та видів аутсорсингу;

- доведено, що термін «персистентність діяльності» не використовувався в економічній науці, а в основному застосовується в області екології, біології, математики, а в останні роки і в інформаційних технологіях та нами сформована система критеріальної оцінки персистентної трансформації харчової проми- словості в системі оцінювання персистентності діяльності іiі суб'єктів в контексті забезпечення іiі конкурентоспроможності;

- подальших досліджень потребує вивчення напрямів та особливостей розвитку аутсорсингової діяльності для окремих суб'єктів національної економіки в Україні, наприклад, харчової промисловості, на підставі зарубіжного досвіду та досліджень вітчизняних вчених.

\title{
Література
}

1. Купріна Н.М. Забезпечення конкурентоспроможності харчової промисловості України: теорія і практика: монографія. Одеса: Видавничий дім «Гельветика», Одеса. 2019. 304 с.

2. Антонюк Л.Л. Міжнародна конкурентоспроможність країн: теорія та механізм реалізації. Київ: КНЕУ, 2004. 275 c.

3. Шлафман Н.Л. Механізми регулювання розвитку підприємницкого сектору: монографія. Херсон: ХНТУ, ІПРЕЕД НАН України, 2010. 284 с.

4. Савенко I.І. Логістичний підхід в управлінні потоками зерно зберігаючи підприємств. Теоретикоправовий та методологічний аспекти: монографія. Одеса: Поліграф, 2008. 272 с.

5. Баранюк Х.О. Забезпечення конкурентоспроможності підприємств малого бізнесу в харчовій промисловості: дис. ... докт. філос: 051: захист 15.12.2020 / наук. кер. Н.М. Купріна. Одеса: ОНАХТ, 2020.217 с.

6. Управление отношениями с поставщиками // Siemens PLM Sofware. URL: http://www.plm.automation.siemens.com/ru_ru/products/teamcenter/solutions_by_product/supplier_relationship_mana gement. (дата звернення: 21.04.2021).

7. Савенко I.I. Чи можна відносити послуги до зернових складів із зберігання збіжжя до аутсорсінгу? // Зернові продукти і комбікорми. 2009. №3(35). С. 4-7.

8. Хамел Г., Прахалад К. Конкурируя за будущее. Москва: Олимп-Бизнес, 2002. 216 с.

9. Кислый В., Жарик Т. Развитие транспортно-логистических кластеров в Украине // Экономика Украины. 2010. №12(581). С.28-37.

10. Товстых А.С. Новая инновационная сфера в экономике третього тысячелетия и новые задачи // Инновации № 6, 2003. С. 39-48.

11. Куприна Н.М. Персистентность деятельности в системе управления реструктуризацией предприятий пищевой промышленности // Социально-экономические явления и процессы: международный научнотеоретический журнал. 2013. №3(049). С. 88-92.

Стаття надійшла 29.04.2021

Стаття прийнята до друку 13.05.2021

Доступно в мережі Internet 21.07.2021

\author{
Kuprina $\mathbf{N}$. \\ Doctor of Economics, Associate Professor \\ Department of Accounting and Auditing \\ Odessa National Academy of Food Technologies \\ Kanatna str., 112, Odesa, Ukraine, 65039 \\ E-mail:k.natali_@ukr.net \\ ORCID ID: 0000-0003-4645-545X
}

\section{DEVELOPMENT OF MODERN BUSINESS STRATEGIES AND OUTSOURCING ACTIVITIES OF NATIONAL ECONOMY SUBJECTS: ESSENCE AND DIRECTIONS}

In modern conditions of activity and development of subjects of national economy of Ukraine,the research of foreign experience and researches of domestic scientists concerning realization of modern business strategies and introduction of new directions of activity of subjects of national economy in Ukraine for maintenance of efficiency of their functioning and competitiveness is actual. A study of scientific publica- 
tions has shown that outsourcing, as a line of business entities based on business partnerships, is treated differently, but the most common in outsourcing activities are currently IT outsourcing, ITS outsourcing, business process outsourcing, production outsourcing, including contracting and subcontracting, but current global trends in the development of enterprises are aimed at services and information technology and obtaining "key competencies" based on cooperation and competition, use of the benefits of small and medium enterprises, as evidenced by foreign experience of public-private partnership. It has been substantiated that in order to ensure the competitiveness and efficiency of the func tioning of the national economy in Ukraine, their economic transformation is necessary - persistent, which in the current economic conditions of its subjects, is aimed at hard, moderate and soft transformation, where soft transformation of activity is the realization of outsourcing activity of subjects on the basis of different approaches of activity and types of outsourcing. A system of criterion assessment of the persistent transformation of the food industry in the system of assessing the persistence of its entities in the context of ensuring its competitiveness has been developed.

Key words: outsourcing, outsourcing activity, subjects of national economy, persistence of activity, persistent transformation of activity, ensuring of competitiveness.

\section{References}

1. Kuprina, N. M. (2019). Zabezpechennia konkurentospromozhnosti kharchovoi promyslovosti Ukrainy: teoriia i praktyka. Vydavnychyi dim «Helvetyka».

2. Antoniuk, L. L. (2004). Mizhnarodna konkurentospromozhnist krain: teoriia ta mekhanizm realizatsii. KNEU.

3. Shlafman, N. L. (2010). Mekhanizmy rehuliuvannia rozvytku pidpryiemnytskoho sektoru. KhNTU, IPREED NAN Ukrainy.

4. Savenko, I. I. (2008). Lohistychnyi pidkhid v upravlinni potokamy zerno zberihaiuchy pidpryiemstv. Teoretyko-pravovyi ta metodolohichnyi aspekty. Polihraf.

5. Baraniuk, Kh. O. (2020). Zabezpechennia konkurentospromozhnosti pidpryiemstv maloho biznesu v kharchovii promyslovost (dissertation). ONAKhT, Odesa.

6. Upravlenie otnosheniyami s postavschikami. Siemens PLM Sofware. http://www.plm.automation.siemens.com/ru_ru/products/teamcenter/solutions_by_product/supplier_relationship_mana gement.

7. Savenko, I. I. (2009). Chy mozhna vidnosyty posluhy do zernovykh skladiv iz zberihannia zbizhzhia do autsorsinhu? Zernovi produkty i kombikormy, (3(35), 4-7.

8. Hamel, G., \& Prahalad, K. (2002). Konkuriruya za buduschee. Olimp-Biznes.

9. Kislyiy, V., \& Zharik, T. (2010). Razvitie transportno-logisticheskih klasterov v Ukraine. Ekonomika Ukrainyi, (12(581), 28-37.

10. Tovstyih, A. S. (2003). Novaya innovatsionnaya sfera $v$ ekonomike tretogo tyisyacheletiya i novyie zadachi. Innovatsii, (6), 39-48.

11. Kuprina, N. M. (2013). Persistentnost deyatelnosti v sisteme upravleniya restrukturizatsiey predpriyatiy pischevoy promyishlennosti. Sotsialno-ekonomicheskie yavleniya $i$ protsessyi: mezhdunarodnyiy nauchnoteoreticheskiy zhurnal, (3(049), 88-92.

Received 29 April 2021

Approved 13 May 2021

Available in Internet 21.07.2021

Цитування згідно ДСТУ 8302:2015

Купріна Н.М. Розвиток сучасних бізнес-стратегій та аутсорсингової діяльності суб'єктів національної економіки: сутність та напрями // Економіка харчової промисловості. 2021. Т. 13, вип. 2. С. 3-8. doi: 10.15673/fie.v13i2.2034

Cite as APA style citation

Kuprina, N. (2021). Development of modern business strategies and outsourcing activities of national economy subjects: essence and directions. Food Industry Economics, 13(2), 3-8. doi: 10.15673/fie.v13i2.2034 